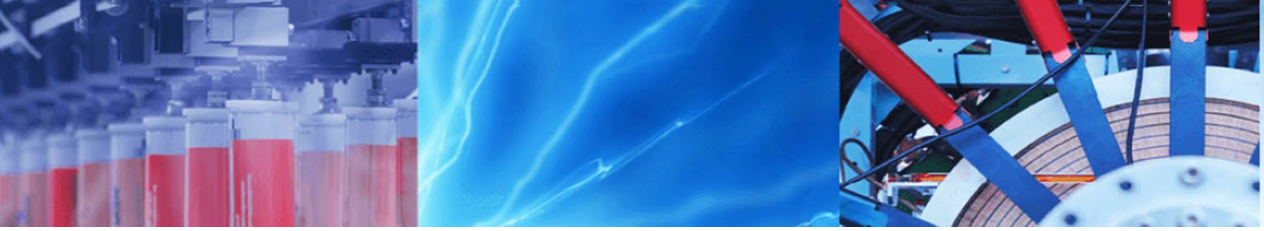

Research Article

\title{
A comparison of kombucha SCOBY bacterial cellulose purification methods
}

\author{
Ananda S. Amarasekara ${ }^{1} \cdot$ Deping Wang ${ }^{1} \cdot$ Tony L. Grady ${ }^{1}$
}

Received: 2 October 2019 / Accepted: 6 January 2020 / Published online: 20 January 2020

(c) Springer Nature Switzerland AG 2020

\begin{abstract}
Kombucha SCOBY pellicle formed as a waste product in the kombucha tea fermentation industry can be used as a potential source for bacterial cellulose. We have compared four simple, scalable purification methods for the purification of this jelly like cellulosic matrix containing bacteria, yeast cells, proteins and polyphenols as impurities. The method using two successive $1.0 \mathrm{M} \mathrm{NaOH}$ washings at $90^{\circ} \mathrm{C}$, followed by the treatment with $1.5 \%(\mathrm{w} / \mathrm{w})$ aq. $\mathrm{NaOCl}$ for $2 \mathrm{~h}$, was the most effective method and gave the purified cellulose sample with the highest leucometer whiteness value of $81.4 \pm 4.8$. The purified cellulose samples were analyzed using FT-IR, TGA, SEM, EDX, X-ray and water absorption at room temperature.
\end{abstract}

Keywords Kombucha $\cdot$ Scoby $\cdot$ Bacterial cellulose $\cdot$ Hydrogen peroxide $\cdot$ Sodium hypochlorite

\section{Introduction}

Kombucha is the common name given to a fermented lightly alcoholic beverage prepared using sweetened black or green tea. Sometimes the beverage is called kombucha tea as well to differentiate from the bacteria and yeast culture used in the fermentation process. This centuries old beverage is believed to have been originated in northeastern china. The current broad attention to this classical beverage due to renewed interest in supposed health benefits has resulted a number commercial scale productions and a home brewing renaissance [1, 2]. Kombucha culture is composed of a symbiotic growth of acid producing bacteria and osmophilic yeast species in a zoogleal mat. During the kombucha tea fermentation a gelatinous, cellulose-based biofilm or a pellicle is formed at the air-liquid interface. This biofilm is a Symbiotic Culture of Bacteria and Yeast (SCOBY) and commonly known as a tea mushroom as well. The microbial populations in a SCOBY may vary, but generally include Acetobacter bacterial species, various Saccharomyces and a number other types of yeasts [3]. Within this culture, anaerobic ethanol fermentation by yeast, organic acid fermentation and aerobic ethanol oxidation to acetate through bacteria can all take place concurrently along an oxygen gradient. In addition, Acetobacter may well polymerize glucose residues forming a bacterial cellulose mat supporting the microbial culture $[3,4]$.

In recent years, with the surge of the kombucha beverage industry, a number of research groups around the globe have studied the microbial culture, composition of the fermented liquid as well as the bacterial biofilm at the water-air interface. The major components of the fermented media are gluconic, acetic, lactic acids and ethanol; in addition, minor amounts of proteins, tea polyphenols, minerals and vitamins (B1, 2, 6, 12 and $C$ ) are also reported $[4,5]$. The pellicle formed at the air-liquid interface is mainly cellulose. Similar bacterial cellulose forms

Electronic supplementary material The online version of this article (https://doi.org/10.1007/s42452-020-1982-2) contains supplementary material, which is available to authorized users.

Ananda S. Amarasekara, asamarasekara@pvamu.edu| 'Department of Chemistry, Prairie View A\&M University, Prairie View, TX 77446, USA. 
are known for several decades and is traditionally isolated from nata de coco, a gelatinous southeast Asian dessert made from coconut water [6]. In this preparation coconut water serves as the carbon source for bacteria Acetobacter xylinum and later converted to extracellular cellulose [6]. In comparison with plant cellulose, microfibrils of bacterial cellulose are generally about 100 times smaller than in plant cellulose and this fine structure leads to a number of appealing properties of bacterial cellulose, such as high water absorption capacity and strength $[7,8]$. In addition, the well arranged three dimensional nano-fiber network in bacterial celluloses results the formation of hydrogel sheets with high surface area, abundant surface hydroxyl groups, high porosity and good chemical-modifying capacity $[9,10]$. As a result bacterial cellulose has found in numerous applications such as wound dressing [11, 12], raw material for food and as food packaging [13], bioreactor, bio-processing [14], optoelectronics [15], polymer electrolyte membranes [16], and many medical applications such as: implants and scaffolds for tissue engineering of cartilage as well as carriers for drug delivery [17-19].

Our interest in processing cellulosic biomass for renewable fuels and chemical feedstock applications has led us to study the kombucha pellicle formed as a waste product in the growing kombucha beverage industry as a potential new sources of bacterial cellulose [20-22]. Under this program, we have studied the probable industrially scalable methods for the purification of kombucha pellicle to produce bacterial cellulose. In this publication, we present a comparison of four simple methods and identification of the best conditions for the purification of bacterial cellulose formed as a waste product in the kombucha tea industry.

\section{Experimental}

\subsection{Materials and instrumentation}

The starting kombucha SCOBY was purchased from www. poseymom.com. Lipton black tea (100 tea bags, total $226 \mathrm{~g}$ ) was purchased from local grocery store. Sodium hydroxide (>99\%), sucrose ( $>99 \%)$, sodium hypochlorite solution (6\%) and hydrogen peroxide (3\%) were purchased from Aldrich Chemical Co. Attenuated total reflection infrared (ATR-IR) spectra of cellulose films were recorded in the $650-4000 \mathrm{~cm}^{-1}$ range on a Smiths IdentifyIR spectrometer with a diamond ATR (Danbury, CT, USA). Thermogravimetric analysis was carried out in air using a Perkin Elmer Diamond TG/DTA, High Temp 115. The mass of the thin film piece used for a TG scan was approximately $10 \mathrm{mg}$, and platinum crucibles were used in all experiments. The TG curves were recorded in the $25-600{ }^{\circ} \mathrm{C}$ temperature range using a scanning rate of $20^{\circ} \mathrm{C} \mathrm{min}^{-1}$. Cellulose film thickness was measured using a Pittsburgh instruments digital micrometer model 895. Whiteness of purified cellulose films were measured using Landtek GM-6 Leucometer. Scanning electron microscopy (SEM) and Energy Dispersive X-ray Spectroscopy (EDX) analyses were performed using a JEOL JSM-6010LA using InTouchScope software. The backscattered electron images was collected using an accelerating voltage of $10 \mathrm{kV}$ and a load current $\sim 90 \mu \mathrm{A}$ with a working distance of $9 \mathrm{~mm}$. EDS spectra were collected at a magnification of $500 \times$ and the analyzed area was $0.15 \mathrm{~mm}^{2}(110 \mu \mathrm{m} \times 135 \mu \mathrm{m})$. Qualitative and quantification elemental composition was performed with the characteristic $x$-ray using a silicon-drift detector. The semiquantification is based on the theoretical correction of the ZAF effect. X-ray diffraction experiments were performed using a Bruker D8 Davinci spectrometer, wavelength $1.54060 \AA$, with $40 \mathrm{kV}, 15 \mathrm{~mA} / \mathrm{Cu}$ source, and scan type: $2 \theta$.

\subsection{Preparation of the kombucha pellicle}

Tea was brewed by using Lipton black tea $(11.3 \mathrm{~g}$, five tea bags) and $1.0 \mathrm{~L}$ of boiling water and allowed to stand for $20 \mathrm{~min}$. The tea bags were then removed, sucrose (100 g, $0.292 \mathrm{~mol}$ ) was dissolved in tea and allowed to cool to $37^{\circ} \mathrm{C}$ and kombucha SCOBY was added. The sweetened tea with the starting SCOBY was then covered with a cotton cloth and allowed to stand in a dark cupboard for 10 days. Then the new kombucha pellicle formed at the air-water interface was carefully removed, washed with deionized water $(2 \times 500 \mathrm{~mL})$ and pat dried with Kleenex tissues and used for the purification experiments.

\subsection{Purification of the bacterial cellulose in kombucha pellicle}

The kombucha pellicle was cut into four approximately equal in size quarters and labeled as $A, B, C$ and $D$ and purified using four different methods.

\subsubsection{Purification of kombucha pellicle portion A}

Kombucha pellicle portion A was placed in $50 \mathrm{~mL}$ of $1.0 \mathrm{M}$ aqueous sodium hydroxide solution and allowed to stand at room temperature $\left(23^{\circ} \mathrm{C}\right)$ for $1.0 \mathrm{~h}$. Then removed from the sodium hydroxide solution and washed with deionized water $(6 \times 500 \mathrm{~mL})$, pat dried with Kleenex tissues and weighed. The pellicle portion was then placed in a second $50 \mathrm{~mL}$ of $1.0 \mathrm{M}$ aqueous sodium hydroxide bath, allowed to stand at room temperature $\left(23^{\circ} \mathrm{C}\right)$ for $1.0 \mathrm{~h}$ washed with deionized water dried and weighed as in the earlier treatment. Next the pellicle portion A was placed in $50 \mathrm{~mL}$ of $1.5 \%(\mathrm{w} / \mathrm{w})$ aqueous hydrogen peroxide, allowed to stand 
at room temperature $\left(23^{\circ} \mathrm{C}\right)$ for $2.0 \mathrm{~h}$. Then removed from the hydrogen peroxide bath and washed with deionized water $(6 \times 500 \mathrm{~mL})$, pat dried with Kleenex tissues and weighed. Finally, the pellicle portion A was transferred to a watch glass and dried in an oven at $50^{\circ} \mathrm{C}$ for $20 \mathrm{~h}$ and weighed. The weights after each treatment are shown in Table 1.

\subsubsection{Purification of kombucha pellicle portion B}

Kombucha pellicle portion $B$ was placed in $50 \mathrm{~mL}$ of $1.0 \mathrm{M}$ aqueous sodium hydroxide solution and allowed to stand at room temperature $\left(23^{\circ} \mathrm{C}\right)$ for $1.0 \mathrm{~h}$. Then removed from the sodium hydroxide solution and washed with deionized water $(6 \times 500 \mathrm{~mL})$, pat dried with Kleenex tissues and weighed. The pellicle portion was then placed in a second $50 \mathrm{~mL}$ of $1.0 \mathrm{M}$ aqueous sodium hydroxide bath, allowed to stand at room temperature $\left(23^{\circ} \mathrm{C}\right)$ for $1.0 \mathrm{~h}$ washed with deionized water dried and weighed as in the earlier treatment. Next the pellicle portion B was placed in $50 \mathrm{~mL}$ of $1.5 \%(\mathrm{w} / \mathrm{w})$ aqueous sodium hypochlorite, allowed to stand at room temperature $\left(23^{\circ} \mathrm{C}\right)$ for $2.0 \mathrm{~h}$. Then removed from the sodium hypochlorite bath and washed with deionized water $(6 \times 500 \mathrm{~mL})$, pat dried with Kleenex tissues and weighed. Finally, the pellicle portion $B$ was transferred to a watch glass and dried in an oven at $50^{\circ} \mathrm{C}$ for $20 \mathrm{~h}$ and weighed. The weights after each treatment are shown in Table 1.

\subsubsection{Purification of kombucha pellicle portion C}

Kombucha pellicle portion $C$ was placed in $50 \mathrm{~mL}$ of $1.0 \mathrm{M}$ aqueous sodium hydroxide solution thermostated at $90^{\circ} \mathrm{C}$ for $1.0 \mathrm{~h}$. Then removed from the sodium hydroxide solution and washed with deionized water $(6 \times 500 \mathrm{~mL})$, pat dried with Kleenex tissues and weighed. The pellicle portion was then placed in a second $50 \mathrm{~mL}$ of $1.0 \mathrm{M}$ aqueous sodium hydroxide bath thermostated at $90^{\circ} \mathrm{C}$, allowed to stand for $1.0 \mathrm{~h}$, washed with deionized water, dried and weighed as in the earlier treatment. Next the pellicle portion $\mathrm{C}$ was placed in $50 \mathrm{~mL}$ of $1.5 \%(\mathrm{w} / \mathrm{w})$ aqueous hydrogen peroxide, allowed to stand at room temperature $\left(23^{\circ} \mathrm{C}\right)$ for $2.0 \mathrm{~h}$. Then removed from the hydrogen peroxide bath and washed with deionized water $(6 \times 500$ $\mathrm{mL}$ ), pat dried with Kleenex tissues and weighed. Finally, the pellicle portion $C$ was transferred to a watch glass and dried in an oven at $50^{\circ} \mathrm{C}$ for $20 \mathrm{~h}$ and weighed. The weights after each treatment is shown in Table 1.

\subsubsection{Purification of kombucha pellicle portion D}

Kombucha pellicle portion D was placed in $50 \mathrm{~mL}$ of $1.0 \mathrm{M}$ aqueous sodium hydroxide solution thermostated at $90^{\circ} \mathrm{C}$ for $1.0 \mathrm{~h}$. Then removed from the sodium hydroxide solution and washed with deionized water $(6 \times 500 \mathrm{~mL})$, pat dried with Kleenex tissues and weighed. The pellicle portion was then placed in a second $50 \mathrm{~mL}$ of $1.0 \mathrm{M}$ aqueous sodium hydroxide bath thermostated at $90^{\circ} \mathrm{C}$, allowed to stand for $1.0 \mathrm{~h}$ washed with deionized water, dried and weighed as in the earlier treatment. Next the pellicle portion $D$ was placed in $50 \mathrm{~mL}$ of $1.5 \%(\mathrm{w} / \mathrm{w})$ aqueous sodium hypochlorite, allowed to stand at room temperature $\left(23^{\circ} \mathrm{C}\right)$ for $2.0 \mathrm{~h}$. Then removed from the sodium hypochlorite bath and washed with deionized water $(6 \times 500 \mathrm{~mL})$, pat dried with Kleenex tissues and weighed. Finally, the pellicle portion $\mathrm{D}$ was transferred to a watch glass and dried in an oven at $50^{\circ} \mathrm{C}$ for $20 \mathrm{~h}$ and weighed. The weights after each treatment are shown in Table 1.

\subsection{Analysis of purified kombucha pellicle portions A, B, C and D}

The dried kombucha pellicle portions $A, B, C$ and $D$ were analyzed by FT-IR, TGA and SEM. The thickness of films were measured using a digital micrometer and the whiteness was measured using a Landtek GM- 6 Leucometer. The water absorption of purified, dried kombucha pellicle portions $A, B, C$ and $D$ were measured by immersing a weighed portion of dried kombucha film $(\sim 100 \mathrm{mg})$ in deionized water and weighing the water absorbed sample

Table 1 Weights of kombucha pellicle portions A, B, C and D at various stages of purification

\begin{tabular}{|c|c|c|c|c|c|c|c|c|}
\hline Sample & $\begin{array}{l}\text { Initial weight } \\
\text { (g) }\end{array}$ & $\begin{array}{l}\text { After, } 1.0 \mathrm{M} \\
\mathrm{NaOH}, 23^{\circ} \mathrm{C}, \\
1.0 \mathrm{~h}(\mathrm{~g})\end{array}$ & $\begin{array}{l}\text { After, } 1.0 \mathrm{M} \\
\mathrm{NaOH}, 90^{\circ} \mathrm{C} \\
1.0 \mathrm{~h}(\mathrm{~g})\end{array}$ & $\begin{array}{l}\text { After, } 1.0 \mathrm{M} \\
\mathrm{NaOH}, 23^{\circ} \mathrm{C}, \\
2.0 \mathrm{~h}(\mathrm{~g})\end{array}$ & $\begin{array}{l}\text { After, } 1.0 \mathrm{M} \\
\mathrm{NaOH}, 90^{\circ} \mathrm{C}, \\
2.0 \mathrm{~h}(\mathrm{~g})\end{array}$ & $\begin{array}{l}\text { After, } 1.5 \% \\
(\mathrm{w} / \mathrm{w}) \mathrm{H}_{2} \mathrm{O}_{2} \\
23^{\circ} \mathrm{C}, 2.0 \mathrm{~h}(\mathrm{~g})\end{array}$ & $\begin{array}{l}\text { After, } 1.5 \% \\
(\mathrm{w} / \mathrm{w}) \mathrm{NaOCl} \\
23^{\circ} \mathrm{C}, 2.0 \mathrm{~h}(\mathrm{~g})\end{array}$ & Dry weight (g) \\
\hline A & 40.11 & 43.86 & - & 46.38 & & 46.65 & - & 1.10 \\
\hline B & 41.77 & 47.15 & - & 48.77 & & - & 48.19 & 1.52 \\
\hline C & 39.62 & - & 42.93 & - & 44.89 & 44.76 & - & 1.06 \\
\hline D & 44.37 & - & 47.48 & - & 50.32 & - & 47.67 & 1.54 \\
\hline
\end{tabular}


at different time intervals after pat drying the film portion with Kleenex tissues.

\section{Results and discussion}

\subsection{Purification of kombucha pellicle portions A, B, C and D}

Kombucha pellicle portions $A, B, C$ and $D$ were purified using four different methods. The samples $A$ and $B$ were washed with $1.0 \mathrm{M}$ aq. sodium hydroxide at room temperature, whereas, $C$ and $D$ were washed with the same sodium hydroxide at $90^{\circ} \mathrm{C}$ for a similar time. Then $\mathrm{A}$ and $\mathrm{C}$ were subjected to hydrogen peroxide treatments and $B$ and $D$ were subjected to sodium hypochlorite treatments. The weights of pellicle portions $A, B, C$ and $D$ at various stages of purification are shown in Table 1. Aqueous sodium hydroxide treatment or alkaline treatment is the most widely used method for the purification of cellulose and hemicellulose from plant materials [23]. In this case aqueous sodium hydroxide is known to remove lignin by hydrolyzing ester bonds present between lignin and hemicellulose $[23,24]$. Similarly, in the present experiments $\mathrm{NaOH}$ treatment may help in removing tannins and polyphenols as well as bacteria, yeast cells and proteins, that may be present in minor amounts in the kombucha pellicle. The $\mathrm{NaOCl}[25]$ and $\mathrm{H}_{2} \mathrm{O}_{2}$ [26] are well known bleaching agents in cellulose purification, therefore we have tested these reagents in bleaching the colored impurities in bacterial cellulose from Kombucha.

All samples showed gains in wet weights during sodium hydroxide washings, and this may be due to opening of pores in cellulose structure due to sodium hydroxide washings; allowing more water absorptions, as well as surface absorption of sodium ions. The dry weights of cellulose samples after purification are shown in the last column of Table 1. The hydrogen peroxide treated samples $A$ and $C$ showed much lower dry weights in comparison to the sodium hypochlorite treated samples B and D; this may possibly due to the oxidation of some cellulose with hydrogen peroxide and degradation of the polymer [26].

\subsection{Analysis of purified kombucha cellulose samples $A, B, C$ and $D$}

The leucometer whiteness readings, film thickness, and Total Crystallinity Index (TCl) of purified kombucha cellulose samples A, B, C and D are in Table 2. The sample D purified using sodium hydroxide solution at $90^{\circ} \mathrm{C}$ and sodium hypochlorite treatment showed the highest whiteness of $81.4 \pm 4.8$. Sample A purified using sodium hydroxide solution at room temperature and hydrogen peroxide
Table 2 Leucometer whiteness readings, film thickness, and Total Crystallinity Index (TCl) of purified kombucha cellulose samples $A$, $\mathrm{B}, \mathrm{C}$ and $\mathrm{D}$

\begin{tabular}{llll}
\hline Sample & $\begin{array}{l}\text { Leucom- } \\
\text { eter whiteness } \\
\text { reading }^{\text {a }}\end{array}$ & Thickness $^{\text {a }}(\mathrm{mm})$ & $\begin{array}{l}\text { Total Crystallin- } \\
\text { ity Index }(\mathrm{TCl})^{\mathrm{b}}\end{array}$ \\
\hline A & $23.8 \pm 1.6$ & $0.42 \pm 0.06$ & 3.852 \\
B & $36.3 \pm 1.5$ & $0.41 \pm 0.04$ & 2.900 \\
C & $36.4 \pm 2.3$ & $0.33 \pm 0.08$ & 2.931 \\
D & $81.4 \pm 4.8$ & $0.27 \pm 0.02$ & 2.750 \\
\hline
\end{tabular}

${ }^{\text {a }}$ Average of five readings in each determination

${ }^{\text {b}}$ Total Crystallinity Index (TCl) was measured using FT-IR spectroscopy, and the formula: $\mathrm{TCl}=\left(\right.$ absorption at $\left.1373 \mathrm{~cm}^{-1}\right) /($ absorption at $2900 \mathrm{~cm}^{-1}$ ) [27]. FT-IR spectra of samples are in the supplementary material

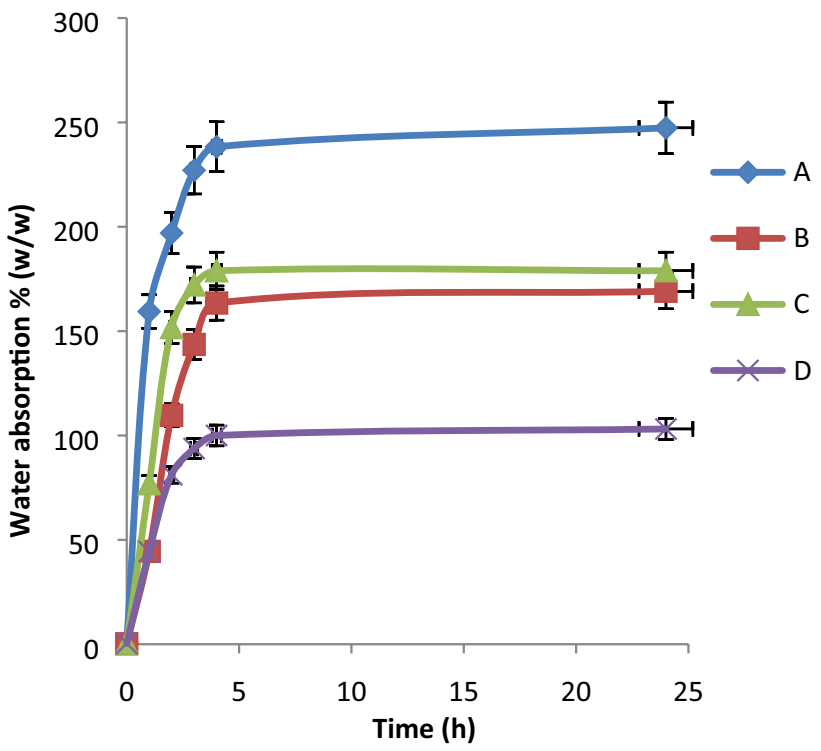

Fig. 1 The percent water absorption ( $w / w)$ of purified kombucha cellulose samples $A, B, C$ and $D$ at room temperature $\left(23^{\circ} \mathrm{C}\right)$

treatment resulted in the lowest whiteness of $23.8 \pm 1.6$ and the darkest sample. In addition, the samples washed with sodium hydroxide at $90^{\circ} \mathrm{C}(\mathrm{C}$ and $\mathrm{D})$ appears to be much thinner than samples washed with sodium hydroxide at room temperature. The total crystalline index (TCl) of all purified samples were calculated using FT-IR spectra as described by Kruer-Zerhus et al. [27] in their work on similar bacterial cellulose samples. The FT-IR spectra are included in the supplementary material and $\mathrm{TCl}$ values were calculated using the formula: $\mathrm{TCl}=$ (absorption at $\left.1373 \mathrm{~cm}^{-1}\right) /\left(\right.$ absorption at $\left.2900 \mathrm{~cm}^{-1}\right)$ [27]. The whitest sample $D$ showed the lowest crystallinity index of 2.750 whereas the darkest sample A showed the highest crystallinity index of 3.852. This is most likely indicating that 


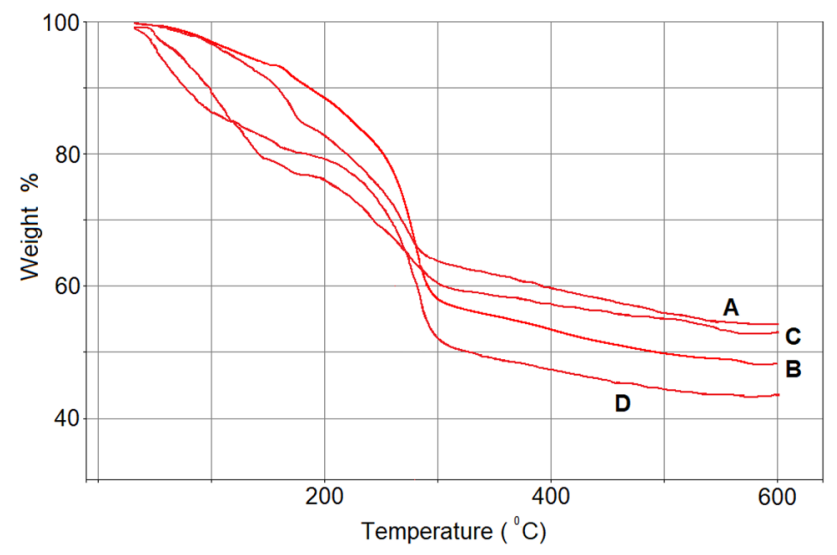

Fig. 2 Thermogravimetric analysis (TGA) curves of purified kombucha cellulose samples A, B, C and D

strong conditions, $1.0 \mathrm{M}$ aq. sodium hydroxide at $90^{\circ} \mathrm{C}$ and $1.5 \%$ sodium hypochlorite treatment used in the purification of sample $D$ can cause reduction in crystallinity of the cellulose as well.

The percent water absorption ( $w / w$ ) of purified kombucha cellulose samples A, B, C and D at room temperature are shown in Fig. 1. All purified cellulose samples reached their maximum water absorption capacities after about $4 \mathrm{~h}$. The highest water absorption of $247 \%$ was seen for sample $A$ and the lowest percent of $103 \%$ was seen for sample $D$. This is the reversed trend of whiteness in the sample; in other words, the highly purified sample showed the lowest water absorption capacity. This may be explained as an increase in water absorption in cellulose as a result of impurities present in the cellulose sample. Furthermore, it is interesting to note that the samples B and $C$ showing similar whiteness readings appears to have similar water absorption capacities.

The thermogravimetric analysis (TGA) curves of purified kombucha cellulose samples $A, B, C$ and $D$ are shown in Fig. 2. All samples showed a rapid decomposition and major weight losses around $270-280^{\circ} \mathrm{C}$ range. The most purified (highest whiteness) sample $D$ showed the lowest residue left at $600{ }^{\circ} \mathrm{C}$ of about $43 \%$, whereas the least purified (lowest whiteness) sample D showed the highest residue of about $55 \%$ at $600{ }^{\circ} \mathrm{C}$. This again indicates the inadequate purification in $\mathrm{A}$, in which the impurities may have contributed to the formation of higher amount of un-burnt chars at $600^{\circ} \mathrm{C}$.
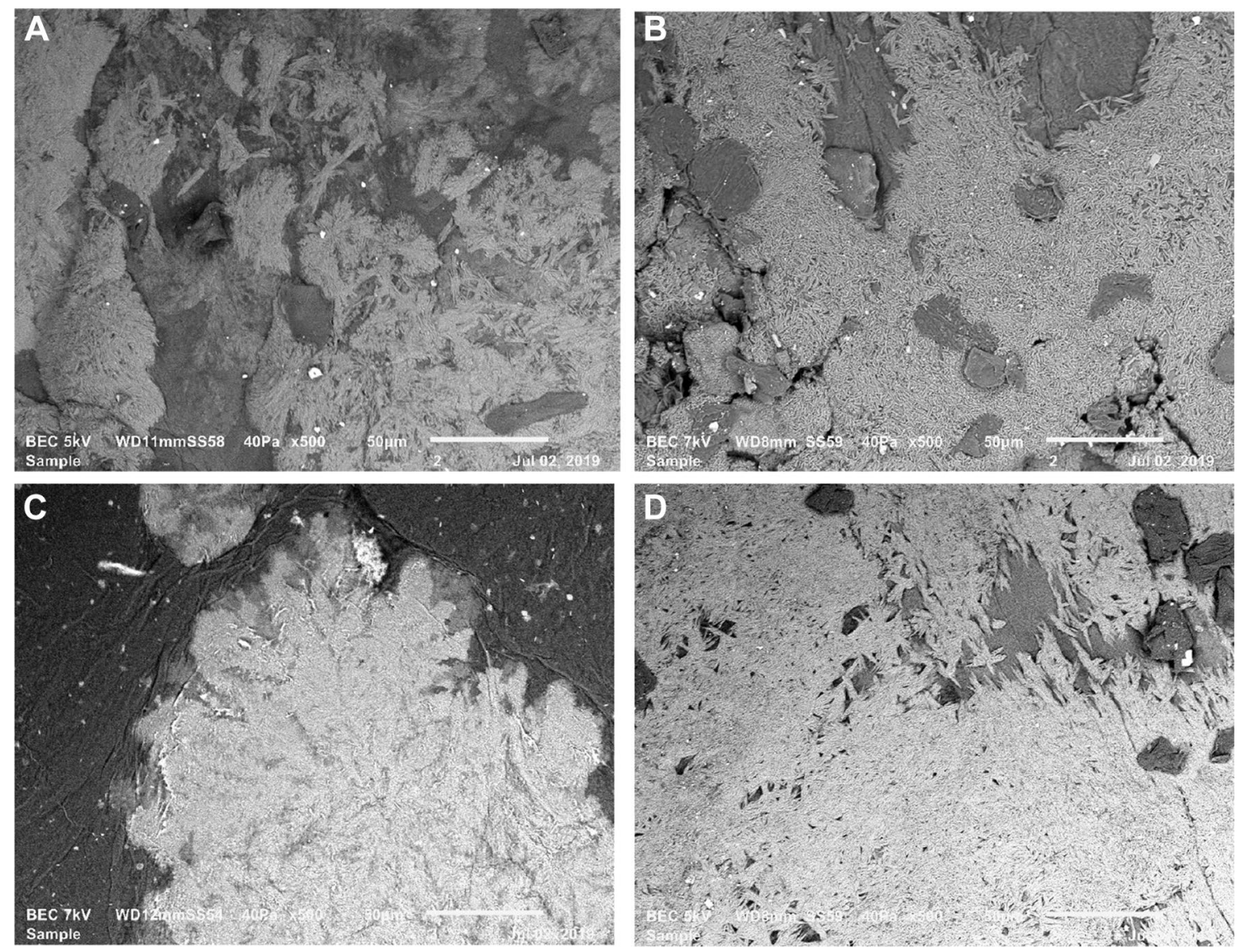

Fig. 3 SEM images of purified kombucha cellulose samples $A, B, C$ and D 
The SEM images of purified kombucha cellulose samples $A, B, C$ and D are shown in Fig. 3. Surface C, O, Na and $\mathrm{Cl}$ elemental analysis \% (w/w) composition data of purified kombucha cellulose samples A, B, C and D from Energy Dispersive X-ray Spectroscopy (EDX) in shown in Table 3. EDX was used to analyze surface elemental composition of purified cellulose samples and compare the changes in surface compositions due to different purification methods. The sample with the highest purity D showed wider homogeneous regions of cellulose fibrils and least amount of dark patches due to impurities. The surface analysis in Table 3 showed the presence of significant amounts of sodium on the surface of all purified cellulose samples, accumulated on the surface during the sodium hydroxide washings. The two samples $B$ and $D$ treated with sodium hypochlorite showed trace amounts of chlorine on the surface as well. The X-ray diffraction profile of kombucha cellulose sample $D$ is shown in Fig. 4. The major diffraction peaks at $2 \theta$ values of $14.5^{\circ}, 16.6^{\circ}$ and $22.6^{\circ}$ in the purified Kombucha cellulose are most likely associated with 110,110 and 200 planes respectively as similar values are

Table 3 Surface $\mathrm{C}, \mathrm{O}, \mathrm{Na}$ and $\mathrm{Cl}$ elemental analysis \% (w/w) composition data of purified kombucha cellulose samples A, B, C and D from Energy Dispersive X-ray Spectroscopy (EDS) (H atoms are not observed in EDS)

\begin{tabular}{lllll}
\hline Sample & $\mathrm{C}$ & $\mathrm{O}$ & $\mathrm{Na}$ & $\mathrm{Cl}$ \\
\hline $\mathrm{A}$ & 28.08 & 49.01 & 22.91 & - \\
B & 27.25 & 48.53 & 23.29 & 0.93 \\
C & 33.26 & 48.47 & 18.27 & - \\
D & 28.28 & 53.24 & 28.00 & 0.48 \\
\hline
\end{tabular}

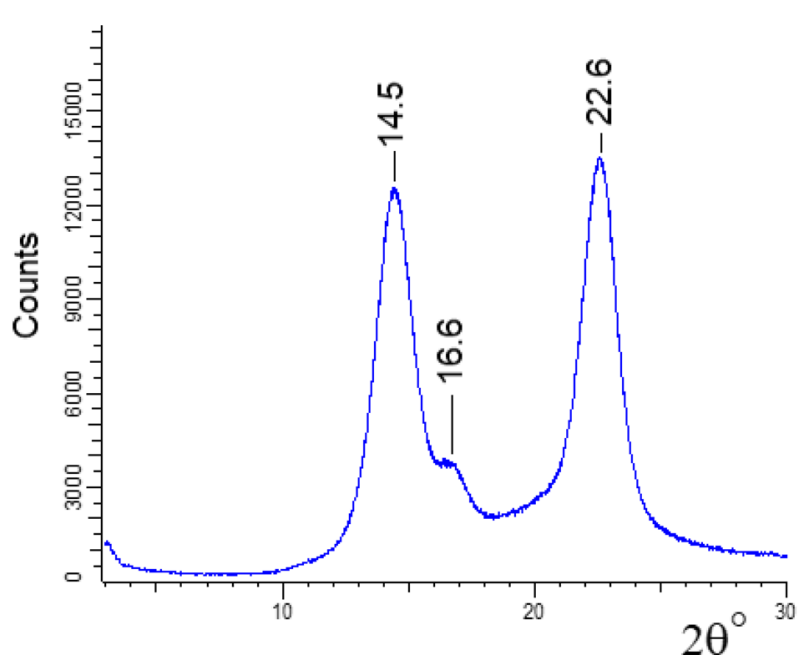

reported for bacterial cellulose samples from Acetobacter xylinum $[28,29]$.

\section{Conclusion}

We have compared four simple and scalable methods for the purification of cellulosic matrix formed as a byproduct in the kombucha tea fermentation process. The purification methods tested involved repeated washings with 1.0 $\mathrm{M}$ aq. sodium hydroxide and bleaching using hydrogen peroxide or sodium hypochlorite. The method using two initial $1.0 \mathrm{M}$ sodium hydroxide washings at $90^{\circ} \mathrm{C}$, and a bleaching with $1.5 \%$ sodium hypochlorite for $2 \mathrm{~h}$, was identified as the most effective technique, which produced the purified cellulose sample with the highest leucometer whiteness value of $81.4 \pm 4.8$. In summary, we have shown that sodium hydroxide washings and dilute sodium hypochlorite treatment can be applied for the purification of bacterial cellulose from kombucha SCOBY pellicle formed as a waste product in kombucha tea fermentation industry.

Acknowledgements Authors would like to thank National Science Foundation of the United States (US-NSF) (through Grant Nos. CBET1704144 and HRD-1036593) for financial support.

\section{Compliance with ethical standards}

Conflict of interest The authors declare that they have no conflict of interest.

\section{References}

1. Dutta H, Paul SK (2019) Kombucha drink: production, quality, and safety aspects. In: Grumezescu AM, Holban AM (eds) Production and management of beverages, vol I. The science of beverages. Elsevier, Amsterdam, pp 259-288

2. Martínez Leal J, Valenzuela Suárez L, Jayabalan R, Huerta Oros J, Escalante-Aburto A (2018) A review on health benefits of kombucha nutritional compounds and metabolites. CyTA J Food 16:390-399

3. Jayabalan R, Malbaša RV, Lončar ES, Vitas JS, Sathishkumar M (2014) A review on kombucha tea-microbiology, composition, fermentation, beneficial effects, toxicity, and tea fungus comprehensive. Rev Food Sci Food Saf 13:538-550

4. Villarreal-Soto SA, Beaufort S, Bouajila J, Souchard JP, Taillandier $P$ (2018) Understanding kombucha tea fermentation: a review. J Food Sci 83:580-588

5. Jayabalan R, Marimuthu S, Swaminathan K (2007) Changes in content of organic acids and tea polyphenols during kombucha tea fermentation. Food Chem 102:392-398

6. Halib N, Amin M, Ahmad I (2012) Physicochemical properties and characterization of nata de coco from local food industries as a source of cellulose. Sains Malays 41:205-211

Fig. 4 X-ray diffraction profile of kombucha cellulose sample D 
7. Chawla PR, Bajaj IB, Survase SA, Singhal RS (2009) Microbial cellulose: fermentative production and applications. Food Technol Biotechnol 47(2):107-124

8. Gayathry G, Gopalaswamy G (2014) Production and characterisation of microbial cellulosic fibre from Acetobacter xylinum. Indian J Fib Text Res 39:93-96

9. Esa F, Tasirin SM, Rahman NA (2014) Overview of bacterial celIulose production and application. Agric Agric Sci Procedia 2:113-119

10. Klemm D, Heublein B, Fink HP, Bohn A (2005) Cellulose: fascinating biopolymer and sustainable raw material. Angew Chem Int Ed 44:3358-3393

11. Lin W-C, Lien C-C, Yeh H-J, Yu C-M, Hsu S-h (2013) Bacterial cellulose and bacterial cellulose-chitosan membranes for wound dressing applications. Carbohydr Polym 94:603-611

12. Qiu Y, Qiu L, Cui J, Wei Q (2016) Bacterial cellulose and bacterial cellulose-vaccarin membranes for wound healing. Material Sci Eng C 59:303-309

13. Azeredo H, Barud HS, Farinas CS, Vasconcellos VM, Claro AM (2019) Bacterial cellulose as a raw material for food and food materials packaging applications. Front Sustain Food Syst. https ://doi.org/10.3389/fsufs.2019.00007

14. Cacicedo ML et al (2016) Progress in bacterial cellulose matrices for biotechnological applications. Bioresour Technol 213:172-180

15. Khan S, UI-Islam M, Khattak WA, Ullah MW, Park JK (2015) Bacterial cellulose-poly(3,4-ethylenedioxythiophene)-poly (styrenesulfonate) composites for optoelectronic applications. Carbohydr Polym 127:86-93

16. Vilela C, Martins A, Sousa N, Silvestre A, Figueiredo F, Freire C (2018) Poly (bis[2-(methacryloyloxy)ethyl]phosphate)/bacterial cellulose nanocomposites: preparation, characterization and application as polymer electrolyte membranes. Appl Sci 8:1145

17. Rajwade J, Paknikar K, Kumbhar J (2015) Applications of bacterial cellulose and its composites in biomedicine. App Microbiol Biotechnol 99:2491-2511

18. Stumpf TR, Yang X, Zhang J, Cao X (2018) In situ and ex situ modifications of bacterial cellulose for applications in tissue engineering. Mater Sci Eng C 82:372-383

19. Svensson A, Nicklasson E, Harrah T, Panilaitis B, Kaplan DL, Brittberg M, Gatenholm P (2005) Bacterial cellulose as a potential scaffold for tissue engineering of cartilage. Biomaterials 26:419-431

20. Amarasekara AS (2013) Handbook of cellulosic ethanol. Wiley, NewYork

21. Amarasekara AS, Owereh OS (2009) Homogeneous phase synthesis of cellulose carbamate silica hybrid materials using 1-n-butyl-3-methylimidazolium chloride ionic liquid medium. Carbohydr Polym 78:635-638

22. Amarasekara AS, Owereh OS (2009) Hydrolysis and decomposition of cellulose in bronsted acidic ionic liquids under mild conditions. Ind Eng Chem Res 48:10152-10155

23. Hivechi A, Bahrami SH (2016) A new cellulose purification approach for higher degree of polymerization: modeling, optimization and characterization. Carbohydr Polym 152:280-286

24. Subhedar PB, Gogate PR (2014) Alkaline and ultrasound assisted alkaline pretreatment for intensification of delignification process from sustainable raw-material. Ultrason Sonochem 21:216-225

25. Lewin M, Sello SB (2017) Hypochlorite. Handbook of fiber science and technology, vol 1. Marcel Dekker, New York, pp 256-266

26. Zeronian S, Inglesby M (1995) Bleaching of cellulose by hydrogen peroxide. Cellulose 2:265-272

27. Kruer-Zerhusen N, Cantero-Tubilla B, Wilson DB (2018) Characterization of cellulose crystallinity after enzymatic treatment using Fourier transform infrared spectroscopy (FTIR). Cellulose 25:37-48

28. Kim D-Y, Nishiyama Y, Kuga S (2002) Surface acetylation of bacterial cellulose. Cellulose 9:361-367

29. Takai M, Tsuta Y, Hayashi J, Watanabe S (1975) Biosynthesis of cellulose by Acetobacter Xylinum. III. X-ray studies of preferential orientation of the crystallites in a bacterial cellulose membrane. Polym J 7:157-164

Publisher's Note Springer Nature remains neutral with regard to jurisdictional claims in published maps and institutional affiliations. 